\title{
Karier Subkultur dan Kelompok Marginal: Menelaah Potret Profesi Dominatrix dalam Serial Netflix "Bonding”
}

Prasakti Ramadhana Fahadi

Departemen Ilmu Komunikasi, FISIPOL UGM

prasakti.r.f@ugm.ac.id

\section{ABSTRACT}

The competition for jobs in big cities tends to be tougher for the members of groups that are marginalized and socially stigmatized. As a consequence, alternative cultures and vocations emerge. An example of this is the role of professional dominatrix in the kink or alternative sexuality subculture. Using interpretive analysis method, this article studies youth with other marginal identities-namely 'woman', 'homosexual', and 'working-class member' - in regards to their choice to pursue their career in kink subculture as a professional dominatrix in Netflix's show Bonding. The findings of this research are as follows: The legitimation of alternative sexuality industry as a metropolitan subculture; young people choose to pursue a career, especially in subcultural industry, as a platform as well as motivation for self-actualization, and; jobs in sex and alternative sexuality industry are taken by marginalized young people as an effort to make a living in a big city.

\section{KEYWORDS Kink | Marginalized Group | Subcultural Career | Youth | Netflix Bonding}

\section{PENDAHULUAN}

Usia muda adalah fase transisi dari anakanak yang bersifat dependent, bebas, dan fleksibel, menuju dewasa yang bersifat independen, terikat, dan memiliki tanggung jawab (Minza 2014). Hal ini menjadi salah satu faktor mengapa kaum muda masih cenderung masih menginginkan kebebasan dalam pekerjaan mereka. Keengganan akan keterikatan yang menjadi konsekuensi kebanyakan pekerjaan formal dan masih belum adanya kewajiban untuk menanggung hidup orang lain membuat kaum muda kerap memilih karier dalam sektor-sektor informal, atau bahkan subkultural. Akan tetapi, hal ini bukan menjadi satu-satunya alasan mengapa kaum muda memilih karier subkultural. Di samping memilih berkarier karena ingin mengkomodifikasi hobi, ada kelompok-kelompok pemuda lain yang berkarier di sektor subkultural karena memang melihat peluang di tengah-tengah sulitnya mendapatkan pekerjaan di sektor formal, karena dengan semakin banyaknya lulusan perguruan tinggi, per- saingan tenaga kerja sekarang ini pun menjadi lebih besar dibandingkan beberapa dekade sebelumnya.

Subkultural sendiri diartikan sebagai budaya yang tidak mengikuti arus utama (mainstream), atau bahkan cenderung 'menyimpang' dari norma-norma budaya dominan (Conti 2016). Perkembangan zaman dan perubahan sosial melahirkan fenomena baru dalam dunia karier dan lapangan pekerjaan, yang tidak selalu selaras dengan budaya kerja formal yang dominan. Sebagai contoh, seiring dengan datangnya era kebebasan individu, muncul profesi-profesi yang 'ditentang' secara normatif, seperti drag queen, pole dancer, hingga dominatrix, atau pekerja yang berperan sebagai peran dominan dalam interaksi BDSM (bondage, domination, sadism, dan masochism) di dalam industri seksual. Profesi tersebut yang akan dibahas di dalam tulisan ini melalui analisis interpretif terhadap representasi yang digambarkan oleh serial Netflix berjudul Bonding (2019) yang ditulis dan disutradarai oleh Rightor Doyle. 
Bonding bercerita tentang Tiffany, seorang mahasiswi di New York City yang berprofesi sebagai seorang dominatrix. Tiffany ingin merekrut sahabatnya, Pete, untuk menjadi asistennya. Pete sendiri adalah seorang homoseksual, dan sedang mengalami kesulitan finansial. Artikel ini akan mengkaji potret pemuda marginal yang memutuskan menekuni karier subkultural sebagai dominatrix di kota metropolitan. Selain itu, tulisan ini juga akan membedah nilai-nilai subkultural yang diilustrasikan oleh serial Bonding melalui metode analisis interpretatif. Pertanyaan utama yang ingin dijawab oleh penelitian ini adalah mengapa pemuda marginal di kota besar memilih untuk meniti karier subkultural dan bagaimana serial Bonding merepresentasikan fenomena tersebut.

Selanjutnya, penelitian ini dimaksudkan untuk menjadi karya yang menambah variasi penelitian mengenai pemuda dan karier subkultural di wilayah Urban, misalnya artikel Gregory J. Snyder (2012) yang berjudul The City and the Subculture Career: Professional Street Skateboarding in LA. Artikel tersebut memaparkan secara etnografis karier dalam dunia skateboarding di wilayah urban Los Angeles, Amerika Serikat yang kemudian memberikan kontribusi ke dalam diskusi teori subkultur dan dampak subkultur terhadap kehidupan perkotaan. Selain menyajikan analisis dengan metode, wilayah, dan jenis profesi yang berbeda dengan tulisan Snyder, penelitian ini juga akan memberikan argumen alternatif bahwa kaum muda tidak hanya memilih menggeluti suatu profesi subkultur karena tawaran fleksibilitas berkarier dan unsur 'fun' yang muncul dari komodifikasi hobi, namun juga terdapat alasan-alasan lain yang mendasari keterlibatan mereka di dalam dunia subkultural.

\section{KERJA DAN KEHIDUPAN SUBKULTUR URBAN}

Claude S. Fischer (1995) menjelaskan bahwa definisi dasar dari subkultur adalah "a large set of people who share a defining trait, associate with one another, are members of institutions associated with their defining trait, adhere to a distinct set of values, share a set of cultural tools (dalam Swidler1986)". Subkultur dapat dijelaskan sebagai sekelompok besar orang yang memiliki ciri perilaku yang khas, saling berasosiasi satu sama lain, menjadi anggota dari lembaga-lembaga yang berkaitan dengan ciri perilaku khas mereka, mengikuti sekumpulan nilai yang khas, dan berbagi sekumpulan instrumen kebudayaan (Fischer 1995 p. 544). Definisi lain atas subkultur adalah sebuah sistem pemaknaan hidup, bentuk-bentuk ekspresi atau gaya hidup yang dikembangkan oleh kelompok-kelompok yang posisi sosialnya berada di 'bawah' sebagai respon atas sistem dominan. Hal ini dapat dilihat sebagai upaya mereka untuk menyelesaikan paradoks struktural yang muncul dari konteks sosial yang lebih luas (Nilan, Julian and Germov 2007).

Subkultur merupakan salah satu konsekuensi dari kompleksitas kehidupan perkotaan/urban. Selanjutnya, kehidupan perkotaan yang telah terindustrialisasi secara masif menuntut masyarakatnya untuk saling berkompetisi dalam tekanan yang tinggi dan ritme yang begitu cepat. Hal ini kemudian berdampak pada pergeseran perilaku dan budaya masyarakat menjadi sangat individualistik. Namun, menurut Fischer, individualitas ini pada satu titik dapat pula membentuk kelompok-kelompok masyarakat dengan berbagai ketertarikan, kepentingan, dan preferensi kenikmatan tertentu (Fischer 1995) yang tidak selalu harus sejalan dengan budaya arus utama. Fischer juga berargumen bahwa semakin besar populasi suatu wilayah, semakin tinggi tingkat keragamannya (Ibid., p. 555), dan heterogenisme sedikit banyak menentukan urbanisme (Wirth 1938). Tidak hanya keragaman etnis, tetapi juga keragaman sosial yang meliputi keragaman hobi, cara berelasi, dan gaya hidup. Faktor-faktor inilah yang mendorong munculnya unconventional subcultures, karena menurut teori subkultur, perkotaan menstimulasi unconventionality atau nilai-nilai yang tidak biasa (Fischer 1995 p. 544). Semakin besar populasi suatu wilayah, semakin terspesialisasi, kontras, dan kuatnya subkultur-subkultur yang ada. Semakin urban suatu wilayah, semakin tinggi pula tingkat ke-unconventional-annya (Ibid,. p. 545-6).

Alasan lain dari terbentuknya kelompok-kelompok subkultur adalah besarnya tekanan kehidupan kota dan keinginan untuk mencari kese- 
mpatan berkarir alternatif (Snyder 2017). Tuntutan biaya dan gaya hidup perkotaan yang tinggi terkadang tidak sebanding dengan upah yang diterima para pekerja urban, terutama mereka yang berada di ranah buruh (labor) dan entry level dalam pekerjaan-pekerjaan formal. Terlebih lagi mereka yang termasuk kelompok rentan seperti pemuda, perempuan, individu dengan disabilitas, maupun individu LGBTQ $^{+}$(Lesbian, Gay, Biseksual, Transgender, Queer dan plus/kelompok identitas dan orientasi seksual berbeda lainnya) memiliki kesulitan tersendiri baik dalam mendapatkan posisi di dalam pekerjaan formal maupun mendapatkan upah dan kesempatan berkarier yang setara. Sebagai solusi, kelompok ini kemudian memilih untuk bekerja di dalam sektor informal yang diakomodasi oleh sistem subkultur, baik sebagai pekerjaan utama, maupun pekerjaan sekunder. Sebagai contoh adalah subkultur kehidupan malam yang menawarkan pekerjaan-pekerjaan seperti DJ, bartender, band kafe, penari eksotis dan sebagainya. Contoh lainnya adalah subkultur street community seperti skateboarder, seniman graffiti, breakdancer, 'dan seterusnya.

\section{KELOMPOK MARGINAL: PEREMPUAN, PEMUDA, DAN LGBT+}

Menurut Yogyakarta Principles (2017), salah satu instrument hak asasi manusia (HAM) internasional, definisi kelompok rentan adalah kelompok individu yang memiliki potensi tinggi terhadap kekerasan dan eksklusi sosial. Eksklusi sosial sendiri terjadi ketika individu dibatasi untuk berpartisipasi dalam kehidupan bermasyarakat, sosial, dan ekonomi dan/atau ketika akes mereka terhadap pemasukan dan kesempatan (pribadi, keluarga, budaya) menjadi sangat tidak memadai sehingga mereka tidak dapat memiliki standar hidup yang layak (Gallie and Paugam 2002). Istilah kelompok marginal dapat pula digunakan untuk mendeskripsikan kondisi ini. Menurut laporan tahunan Komisi $\mathrm{Na}^{-}$ sional Hak Asasi Manusia (Komnas HAM 2016), kelompok masyarakat marginal adalah “... mereka yang secara struktural termasuk terpinggirkan untuk memperoleh akses atas keadilan karena berbagai keterbatasan". Sementara itu, European Institute for kelompok marginal sebagai kelompok-kelompok masyarakat dalam kebudayaan, konteks, dan sejarah tertentu yang beresiko menerima diskriminasi ganda dikarenakan interaksi karakteristik personal seperti jenis kelamin, gender, usia, etnis, agama atau kepercayaan, status kesehatan, disabilitas, orientasi seksual, pendidikan atau pendapatan, atau lokasi geografis. Apabila ditinjau dari sudut pandang HAM, kelompok minoritas juga termasuk ke dalam kelompok marginal. Kelompok minoritas sendiri dapat didefinisikan sebagai "...entitas sosial yang sedikit dari sisi populasi (dalam berbagai level geografis), tidak dominan, serta mengalami perlakuan yang diskriminatif.... Serupa dengan definisi kelompok marginal versi EIGE, Komnas HAM menyebutkan bahwa anggota masyarakat yang termasuk ke dalam kelompok minoritas meliputi kelompok agama dan etnis minoritas, kelompok adat, anak-anak, kelompok usia lanjut, individu dengan disabilitas, $\mathrm{LGBTQ}^{+}$, dan perempuan (KOMNASHAM 2016).

Perempuan di seluruh dunia mengalami berbagai bentuk kekerasan dan diskriminasi baik fisik maupun psikologis. Catatan WHO tahun 2011 menunjukkan bahwa rasio jenis kelamin kelahiran bayi di Asia mencapai 130 laki-laki untuk setiap 100 bayi perempuan. Menurut Mariachiara DiCesare (2014), level rasio ini hanya bisa terjadi dengan banyaknya praktik aborsi selektif atau infantisida yang dipengaruhi oleh budaya seksis di masyarakat. Di negara-negara miskin, kesenjangan jumlah anak laki-laki dan anak perempuan yang bersekolah masih besar karena kebanyakan keluarga dengan penghasilan minim masih mengikuti norma kultural bahwa pendidikan anak bagi laki-laki lebih penting dan menguntungkan secara ekonomi daripada anak perempuan (UNESCO 2003 dalam DiCesare 2014). Padahal, terbatasnya akses pendidikan berdampak sepanjang hidup, bahkan bisa turun temurun, dan menjadi akar marginalisasi dan kerentanan perempuan. Hal ini dapat pula berujung kepada kurangnya kemandirian ekonomi, kesetaraan upah, keseimbangan jam kerja, yang mana kesemua itu mempengaruhi kesehatan dan kesejahteraan perempuan (Kaur 2007) dan dapat meningkatkan risiko kemiskinan (DiCesare 2014). Ketidaksetaraan distribusi 
kuasa kepada perempuan dan laki-laki mengakibatkan subordinasi dan kerentanan sepanjang hidup perempuan dalam berbagai konteks. Dalam konteks sosial, peran perempuan dikerdilkan menjadi hanya sebatas pendukung dan pelayan laki-laki, pengurus rumah tangga, dan objek seksual, sehingga dianggap tidak perlu diberikan ruang dan kesempatan ekonomi maupun politik yang sama dengan laki-laki.

Selain perempuan, kelompok masyarakat lain yang termarginalisasi adalah kelompok LGBTQ ${ }^{+}$. Berbagai riset menunjukkan bahwa kelompok ini lebih rentan terhadap kemiskinan apabila dibandingkan dengan heteroseksual (Badgett, Durso and Schneebaum 2013). Hal ini dikarenakan posisi sosio-ekonomi seseorang berkaitan dengan pengalaman diskriminasi mereka, yang berkaitan pula dengan tingkat gejala depresif dan anxietas (Gamarel, et al. 2012). Kelompok LGBTQ ${ }^{+}$yang masih dianggap menyimpang oleh norma kebanyakan masyarakat membuat mereka kerap mendapatkan stigma, pengucilan, diskriminasi, bahkan intimidasi dan persekusi, baik secara langsung maupun di media sosial. Di Indonesia sendiri, tercatat ada 973 kasus kekerasan terhadap komunitas LGBT di seluruh Indonesia sepanjang tahun 2017 (Zakiah 2018), bahkan bisa lebih banyak lagi apabila kasus yang tidak tercatat diikutkan. Mereka juga masih sering mendapatkan stigma bahkan dari aparat yang menangani kasus mereka. Akibatnya, seringkali aduan berakhir 'damai' atau bahkan tidak selesai. Lebih jauh lagi, hingga akhir tahun 2018, Perkumpulan Keluarga Berencana Indonesia (PKBI) mencatat bahwa terdapat lebih dari 65 peraturan pemerintah daerah yang bersifat diskriminatif terhadap kelompok LGBT.

Sementara itu, kelompok pemuda sendiri, termasuk ke dalam golongan kelompok marginal berdasarkan definisi di dalam laporan Komnasham yang dibahas sebelumnya. Kelompok orang muda secara struktural terpinggirkan untuk memperoleh akses dalam masyarakat karena berbagai keterbatasan, di antaranya usia mental yang dianggap 'belum matang', kurangnya pengalaman, kondisi ekonomi yang belum mapan, dan sebagainya. Di samping itu, energi mereka yang sangat dinamis dan rasa penasaran
PERMAINAN KONTROL DUNIA BDSM DAN DOMINATRIK PROFESIONAL

Definisi BDSM menurut Wiseman (1996) adalah pengalaman stimulasi fisik dan/atau psikologis yang konsensual dan melibatkan permainan power dan/atau rasa sakit yang memberikan rangsangan dan kepuasan seksual. Akan tetapi, satu aspek yang paling penting di dalam hubungan BDSM adalah adanya konsen atau persetujuan satu sama lain (Weinberg 2006). Menurut Benjamin C.

yang tinggi seringkali memungkinkan orang muda untuk mengeksplorasi dan melibatkan diri dalam hal-hal yang berisiko yang membuat mereka menjadi rentan untuk terlibat tindakan criminal, kecelakaan, cedera fisik, dan trauma emosional (Arora, et al. 2015). Kelompok muda juga rentan khususnya terhadap perubahan kondisi ekonomi yang tak terduga (economic shocks), ketidakstabilan sosial, dan konflik. Menurut rekomendasi kebijakan yang disusun oleh Columbia University dan Bidang Representatif Kepemudaan PBB, kelompok usia muda juga hampir tidak pernah dilibatkan dalam pemerintahan dan proses pengambilan keputusan yang diakibatkan oleh hambatan-hambatan secara ekonomi, politik, dan prosedural (Offerdahl, Evangelides and Powers 2014). Selanjutnya, dalam kehidupannya, pemuda juga mengalami kerentanan ketika berada dalam masa-masa transisi, utamanya dari usia anak-anak, menuju usia dewasa secara hukum, dan dari dunia pendidikan menuju dunia kerja (Sutopo and Meiji 2014). Pergeseran dari tidak adanya tanggung jawab terhadap diri sendiri menjadi ada, dan sekaligus tanggung jawab terhadap masa depan membuat pemuda harus menyesuaikan diri yang tidak selalu mudah bagi setiap pemuda. Kondisi ini membuat mereka rentan terhadap depresi ataupun kondisi-kondisi lain yang dapat berujung kepada tidak optimalnya aktualisasi diri. Ketika pekerjaan sudah didapat, pekerjaan tersebut juga bisa memberikan tekanan tersendiri. Banyak pekerjaan yang cenderung mengeksploitasi mereka dengan alasan belum adanya pengalaman. Sebagai contoh adalah program-program magang tanpa bayaran atau kerja serabutan. 
Graham et al. (2016), BDSM atau Bondage-discipline/Dominance-submission/sadomasochism merupakan fenomena sosial yang masih disalahpahami dan membutuhkan studi lebih jauh. BDSM telah menjadi subjek marginalisasi di masyarakat baik dahulu maupun sekarang (Graham, et al. 2016). Aktivitas BDSM tidak harus memuat ke semua aspek, tidak juga harus bersifat ekstrim. Karena itu, sesungguhnya aktivitas BDSM memiliki range yang cukup luas, sehingga dapat menjadi sekedar percobaan pengalaman sekali seumur hidup, dan dapat pula menjadi sebuah gaya hidup (Faccio, Casini and Cipolletta 2014).

Pembagian peran di dalam relasi BDSM terbagi menjadi dua, yaitu dominan (dom) dan submisif (sub). Peran dominan bertugas menjadi 'tuan' dan peran submisif bertugas sebagai 'budak'. Individu yang bermata pencaharian dengan berperan sebagai peran dominan dalam BDSM dikenal dengan istilah dominatrix profesional.

\section{"...(a) professional dominatrix is paid by clients to per- form the role of the dominant in scenarios involving bondage, discipline, dominance, submission, sadomas- ochism, and 'fetishism.' Unlike other sex workers, who must often feign interest and act flirtatiously in order to make clients feel desired, the dominatrix is asked, at times, to express emotional displays such as indif- ference or displeasure" (Pinksy and Levey 2015).}

Berbeda dengan hubungan BDSM konsensual resiprokal, dominatrix profesional memiliki peranan dalam hubungan BDSM konsensual sebagai pertukaran komersial (McClintock 1993 dalam Pinksy dan Levey 2015). Profesi dominatrix professional termasuk dalam kategori 'sex work' atau 'erotic labor', karena meskipun dominatrix professional secara tipikal tidak perlu berhubungan intim, mereka diberikan kompensasi finansial untuk memenuhi hasrat erotis para klien. Hal ini pulalah yang membedakan mereka dengan profesi pelacur (Lindemann 2012 dalam Pinksy dan Levey 2015). Klien-klien ini menggunakan jasa dominatrix professional untuk berbagai macam pengalaman, termasuk hukuman fisik, bondage atau pemasungan, dan penghinaan.

Dominatrix professional dapat bekerja sendiri secara freelance, maupun menggabungkan diri dengan agen atau rumah-rumah yang khusus menyediakan jasa dominatrix. Menurut pengalaman pribadi penulis dan filmmaker yang pernah berkarier sebagai dominatrix professional Stavroula Toska, rumah agensinya mengenakan biaya USD $240 \mathrm{ke}-$ pada klien untuk setiap jam mereka menggunakan jasa dominatrix, USD 80 untuk si dominatrix dan sisanya untuk mereka sendiri (Toska 2019). Memang terhitung 'sedikit', namun dengan sistem agensi seperti ini, tentunya keamanan pekerja lebih terjamin, dan setiap kali masuk, mereka akan selalu mendapatkan jatah klien. Di sisi lain, dominatrix yang memilih bekerja lepas menerima $100 \%$ pembayaran, namun harus menghadapi risiko yang lebih tinggi.

\section{METODE PENELITIAN}

Metode yang digunakan dalam penelitian ini adalah metode kualitatif. Metode ini tidak hanya mempelajari konten dari sebuah teks, tetapi juga materi dan penerapannya dalam tindakan-tindakan dalam masyarakat dalam rangka menginvestigasi secara empiris bagaimana media mengkonstruksi makna (Jensen 2013). Objektif daripada metodemetode riset kualitatif meliputi dihasilkannya pemahaman mendalam tentang perilaku manusia dan alasan-alasan di balik itu. Salah satu rubrik di dalam riset kualitatif adalah metode analisis interpretif. Metode ini berupaya untuk membaca konten media dan menarik pemaknaan-pemaknaan sosiokultural di dalamnya. Analisis ini menjadikan konten media sebagai teks yang memberikan panduan dalam memahami fenomena-fenomena sosial, budaya, dan politik di dalam kehidupan sehari-hari (Anderson 2012:324). Metode penelitian ini didasarkan kepada komprehensi dari paradigma komunikasi interpretif (the interpretive paradigm of communication). Para peneliti dalam paradigma ini meyakini bahwa kehidupan memiliki tatanan yang teratur dan kohesif, dan mereka tertarik kepada bagaimana tatanan tersebut berkembang dan berevolusi bagi masing-masing individu (Littlejohn, Foss and Oetzel 2016).

Metode-metode analisis interpretif tidak hanya dapat digunakan untuk mempelajari bagaimana makna terkonstruksi baik dalam proses produksi 
maupun pembacaan, namun juga dapat digunakan untuk berfokus kepada teks itu sendiri. Penelitian ini akan menggunakan metode ini untuk menggali pemaknaan potret pemuda marginal dan profesi dominatrix dalam subkultural seksualitas alternatif/kink di dalam serial Netflix Bonding. Menurut James A. Anderson (2011), yang membedakan analisis interpretif dari analisis isi kuantitatif adalah analisis isi kuantitatif hanya bisa mempertimbangkan presentasi eksplisit dari teks. Tidak seperti analisis isi kuantitatif, analisis interpretif menawarkan metode untuk menelaah sistem pemaknaan non-literal seperti bahasa tubuh, pilihan dan pernyataan fashion, atau atribut-atribut kontekstual lainnya. Penelitian ini akan menggunakan pendekatan tematik dalam pemilihan pembahasan teks yang dikaji. Pendekatan ini membantu peneliti untuk mengerucutkan pembahasan teks berdasarkan tema sosiokultural tertentu (Anderson 2011).

\section{TEMUAN DAN PEMBAHASAN}

Dari ke-delapan episode serial Bonding yang masing-masing berdurasi sekitar 12-17 menit, dilakukan pemilihan adegan dan plot secara tematik. Tema-tema yang dipilih meliputi (1) pekerjaan tokoh Tiffany dan Pete sebagai dominatrix, (2) subkultur dan kehidupan di kota besar, (3) character development dari Tiffany dan Pete, dan (4) identitas Tiffany dan Pete sebagai anggota kelompok marginal. Dari pemilihan adegan-adegan yang termasuk dalam tema-tema tersebut, dilakukan pemaknaan yang kemudian dianalisis sebagai berikut:

\section{A. Industri Seks "bawah Tanah" Sebagai Subkultur Masyarakat Perkotaan}

Serial Bonding bercerita tentang dua sahabat, Tiffany dan Pete, yang tinggal di kota New York, Amerika Serikat. Di episode pertama, Pete menemui Tiffany di tempat kerjanya untuk pertama kali. Tempat kerja Tiffany tersebut diilustrasikan sebagai unit apartemen yang terletak di lantai basement atau bawah tanah dengan penerangan lampu merah dan ruangan-ruangan tertutup di dalamnya. Di dalam ruangan Tiffany terdapat palang kayu tempat kliendiikat, dan berbagai sex toys. Di situlah Tiffany meminta Pete untuk bekerja sebagai asistennya dengan tugas sebagai bodyguard dan membantu membereskan dan membersihkan ruangan sebelum dan sesudah bertemu dengan klien.
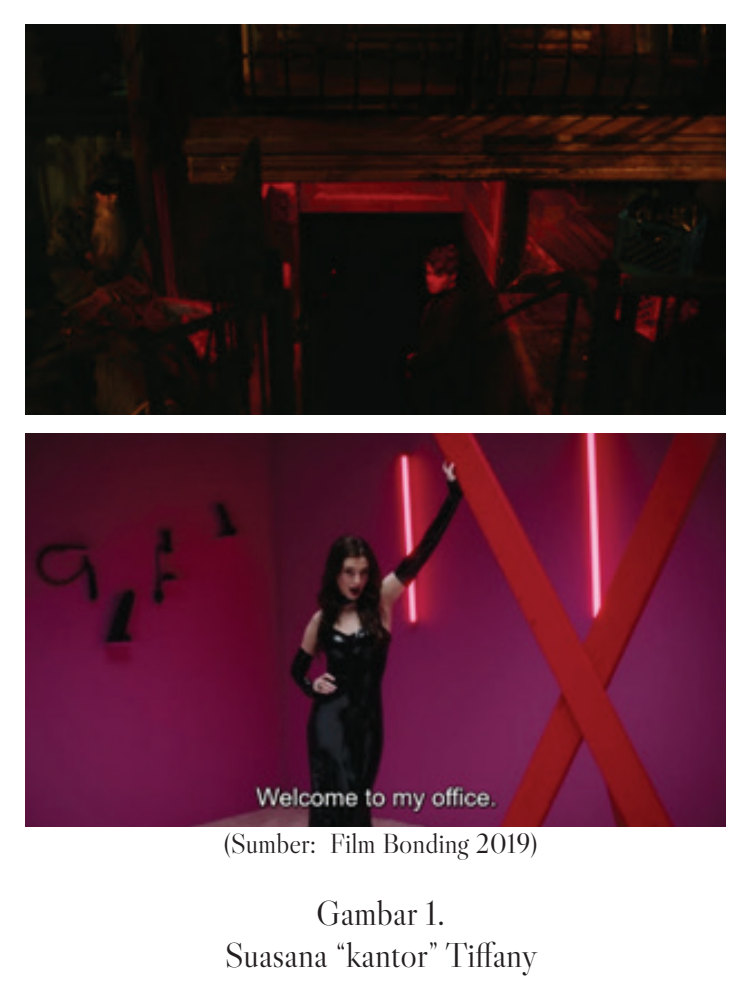

Di dalam Encyclopedia of the City, kehidupan kota besar seperti New York yang merupakan setting lokasi dari Bonding memang kerap dijelaskan dengan model relasi antarkelompok yang disebut Melting Pot, di mana kelompok mayoritas dan minoritas berkumpul dan membaur menjadi satu budaya dan struktur sosial umum, yang kemudian membentuk sebuah budaya dominan. Di sisi lain, model relasi antarkelompok pluralis mempertahankan anggapan bahwa perbedaan subkultur daripada kelompok-kelompok di dalam sebuah budaya umum (common culture), tidak lantas menciptakan melting pot, melainkan mosaik multikultural (Bollens 2005) atau semangkuk salad, yang mana berbagai budaya yang berbeda berbaur, tetapi tetap dengan karakter dan keunikannya masing-masing. Begitu pula dengan industri seks 'bawah tanah'. Terminologi industri seks bawah tanah di sini tidak diartikan sebagai industri seks ilegal yang melibatkan perdagangan manusia dan eksploitasi, namun digunakan untuk menjelaskan dunia BDSM sebagai subkultur 
dari industri seks itu sendiri, mengingat BDSM sendiri identik dengan fetish pemasungan dan penyekapan di dalam penjara bawah tanah (dungeon). Industri seks "bawah tanah" memiliki keunikan tersendiri dibandingkan industri seks lainnya seperti rumah bordil, jasa escort, dan film porno. Berbeda dengan praktik-praktik bisnis seks tersebut, industri BDSM hampir tidak pernah melibatkan kontak seksual sama sekali, sehingga para pelaku di industri ini menolak apabila kegiatan ini dikategorikan sebagai prostitusi. Di Amerika Serikat, prostitusi memang ilegal. Akan tetapi, meskipun dikategorikan bukan prostitusi, industri BDSM malah lebih terstigmatisasi dibandingkan industri seks konvensional. Bahkan di dalam dunia industri seks itu sendiri, BDSM dianggap sebagai aktivitas seksual alternatif yang cenderung menyimpang, imoral, dan tabu. Stigma-stigma tersebut juga meliputi anggapan bahwa BDSM adalah kekerasan dan/atau abuse dan pelakunya memiliki gangguan mental (Sprott and Randall 2016). Padahal, komunitas BDSM memiliki nilai-nilai dan praktik yang secara kuat bertentangan dengan kekerasan dan sangat mengutamakan konsen. Bahkan salah satu moral utama dalam komunitas BDSM sendiri adalah "SSC" atau safe, sane, dan consensual (Sperner 2016).

Stigmatisasi dalam bentuk pelabelan penyimpangan seksual ini, menurut Foucault (1978), adalah hasil dari konstruksi sosial yang diciptakan oleh pihak-pihak yang berkuasa untuk mengontrol populasi. Mendukung pemikiran Foucault ini, Mark Graham (2014) menekankan perlunya kritik tatanan normatif masyarakat, terutama masyarakat barat, dan di sinilah teori Queer berperan. Dalam menjelaskan teori ini, Graham menegaskan bahwa di dalam tatanan normatif tersebut, satu-satunya perilaku seksual atau seksualitas yang dianggap normal adalah heteroseksualitas dan apapun di luar itu maka harus dikategorisasi dan dilabelisasi (Ibid.,). Di episode ke dua, terdapat adegan di mana Tiffany sedang mengajarkan Pete tentang cara mengikat dan tali-temali di dalam BDSM. Sembari melakukan hal tersebut, Tiffany berkata,

"(Dominatrix) Work is about so much more than just

hog-tying someone. It's all about the knot. It's about

the rope pressing against the skin, becoming safer, but more dangerous with every tug. You see, Pete, masculinity is inherently constricting: Expectations, dominance and power, emotionlessness. So, men come to me to escape this crippling societal prison. Once the sexual patriarchy dies, then all genders will be equal."

Di dalam tatanan sosial normatif, peran patriarki tidak bisa dihindari, termasuk dalam mengatur sifat dan sikap maskulinitas toksik yang menuntut laki-laki untuk mendominasi, kuat, berkuasa, dan tidak mengekspresikan perasaan sentimentil. Dengan BDSM, seorang laki-laki dapat melepaskan diri dari itu semua dengan cara melakoni peran yang kontras, yakni sebagai sub, yang bersifat pasrah dan menerima kontrol penuh dari si dom secara konsensual dan berdasarkan respek. Menurut Justin Lehmiller (2018), di dalam industri BDSM, peran dom lebih diminati karena $65 \%$ masyarakat lebih memilih untuk mengambil peran sub. Di samping itu, peran dom sendiri banyak dilakukan oleh perempuan dengan rata-rata klien laki-laki. Meskipun begitu, ada pula dom laki-laki yang melayani pasar sub perempuan dan juga laki-laki homoseksual.

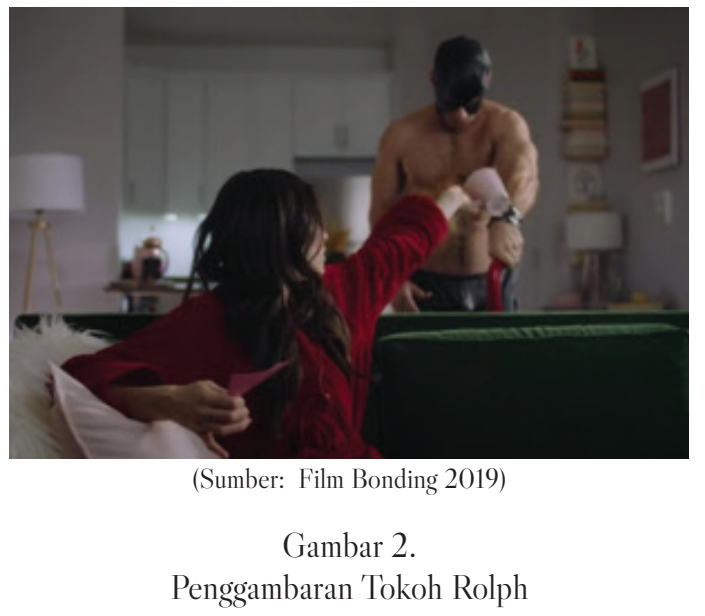

Selanjutnya, meskipun awalnya Pete hanya direkrut untuk menjadi asisten dan bodyguard Tiffany, dalam perjalanannya, Pete kerap membantu Tiffany untuk turut memberikan servis terhadap klien. Di dalam Bonding; setiap klien Tiffany dan Pete meminta servis yang berbeda-beda. Dalam episode pertama, muncul tokoh Rolph (Gambar 2), seorang klien yang meminta untuk diperlakukan layaknya seorang "budak" oleh Tiffany. 
Kemudian, Tiffany dan Pete bekerja sama dalam melayani tokoh Fred yang menginginkan mereka untuk menculik dan menyekapnya. Tiffany lalu menjelaskan kepada Pete bahwa Fred menyukai "torture, wax play, piss play, (dan) humiliation (Bonding 2019)." Selain Rolph dan Fred, klien Tiffany selanjutnya adalah Daphne dan Andy. Sepasang suami istri yang sedang mengalami masalah karena mereka tidak bisa memenuhi fetish masing-masing.

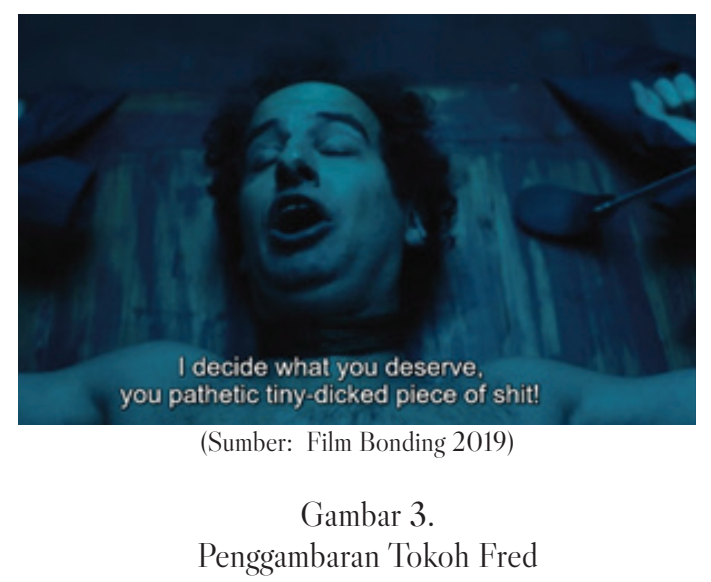

Kehidupan kota besar memang memungkinkan berbagai kelompok dengan latar belakang budaya, etnis, ras, dan ideologi sosial-politik yang berbeda untuk tumbuh, berkembang, dan membentuk subkultur tersendiri. Meskipun begitu, kehidupan kota besar rata-rata berorientasi industrialis dan menciptakan budaya dominan yang cenderung bersifat maskulin, patriarkis, dan-sebagai konsekuensinya-heteronormatif. Industri dan komunitas BDSM hadir sebagai kelompok yang berciri khas dan mencerminkan resistensi terhadap budaya dominan tersebut, baik secara prinsip maupun ekspresi. Dunia BDSM menawarkan sarana pelarian diri' dan 'liberasi' dari tuntutan budaya industrial yang keras, ketat, dan penuh persaingan-sifat-sifat yang tergolong 'maskulin'. Oleh karena itu, sarana liberasi ini memiliki daya tarik tersendiri bagi anggota-anggota masyarakat seperti Rolph; yang digambarkan sebagai pebisnis Eropa yang bekerja di New York, Fred; yang diasumsikan dari penampilannya yang selalu berjas dan berdasi sebagai pekerja elit kantoran, dan Daphne serta Andrew; yang dari penampilan dan gambaran tempat tinggalnya dapat diasumsikan sebagai kalangan menengah ke atas.

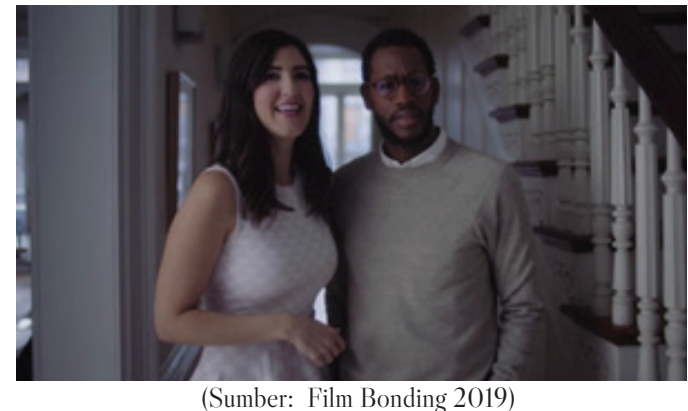

Gambar 4.

Penggambaran Tokoh Daphne dan Andy

B. Berkarier (Subkultural) Sebagai Proses Aktualisasi Diri Pemuda

Dalam serial Bonding, Pete digambarkan sebagai pemuda homoseksual yang mudah cemas, pemalu, dan kurang berani untuk keluar dari zona nyaman. Pete memiliki minat di dunia stand-up comedy, namun di episode-episode awal, ia beberapa kali mengurungkan niatnya untuk maju ke panggung ketika gilirannya tiba. Dunia stand-up comedy merupakan karier yang semula ingin digeluti oleh Pete. Namun kemampuannya untuk mengolah humor secara kreatif belum teraktualisasi dengan baik karena sifat pesimisnya. Setelah Pete menjalani hari-harinya menjadi asisten dominatrix profesional, Pete pun semakin terpapar dengan dunia baru yang sama sekali tidak pernah ia bayangkan dan sangat jauh di luar zona nyamannya: dunia kink; Dunia di mana seolah tidak ada istilah malu; Dunia di mana setiap orang memiliki fetish yang secara normatif dianggap aneh, memalukan, atau menjijikkan, di mana bahkan dipermalukan itu sendiri adalah sebuah kenikmatan. Hal ini mendorong Pete untuk dapat mengekspresikan dirinya tanpa harus memikirkan terlalu serius mengenai tanggapan orang, tanpa harus merasa ragu dan malu. Seperti ketika Fred, salah satu klien, meminta Pete untuk menghinanya, Pete mampu memberikan roasting (hinaan 'cerdas' yang berperspektif humor) yang membuat Fred merasa sangat puas. Seiring berjalannya waktu, Pete semakin berani mengambil inisiatif dalam pekerjaannya sebagai asisten dom. Pada akhirnya, Pete berani naik ke panggung dan mementaskan stand-up nya, lengkap dengan atribut BDSM sebagai tanda bahwa ia telah sepenuhnya menjiwai dan menerima profesinya di dunia kink dan 
'mengawinkan'-nya dengan karier impiannya yaitu sebagai seorang comic. Meskipun diceritakan dengan cukup singkat, keikutsertaan Pete di dalam industri BDSM dapat dikatakan membantunya untuk mengembangkan potensi dirinya. Keikutsertaan tersebut juga sudah dapat dikatakan sebagai karir, karena awalnya Pete hanya berperan sebagai asisten yang bersifat pasif, kemudian dari proses pengembangan diri yang dilakukannya, di akhir season ia menjadi 'partner' yang setara dengan Tiffany. Ilustrasi ini juga dapat dimaknai sebagai proses metamorphosis Pete dari seorang pemuda 'daerah' yang pemalu dan menghabiskan sebagian besar masa remajanya untuk tidak merangkul identitasnya secara utuh sebagai seorang gay, menjadi anggota masyarakat metropolitan yang seutuhnya.

Sementara itu, Tiffany digambarkan sebagai sosok yang dingin, tertutup, dan cenderung sinis. Ia memiliki kesulitan untuk membuka dirinya terhadap orang yang mendekatinya. Meskipun tidak secara eksplisit, Tiffany diceritakan memiliki trauma di masa lalu yang membuatnya begitu takut untuk mengekspresikan sisi rapuhnya. Melihat sifat-sifat tersebut, pekerjaan Tiffany sebagai dom awalnya dirasa sangat menguntungkan dirinya. Akan tetapi, selain bekerja sebagai dominatrix, Tiffany adalah juga seorang mahasiswa psikologi, dan di sinilah sifat-sifat tersebut menjadi bumerang: Di salah satu mata kuliah, Tiffany dan para mahasiswa lainnya ditugaskan untuk mempresentasikan motivasi mereka untuk belajar psikologi, dan psikolog seperti apa yang menjadi aspirasi mereka. Tiffany diperlihatkan cukup merasa kesulitan dalam memenuhi tugas ini. Secara implisit, Tiffany diceritakan bahwa ia menganggap kariernya sebagai dominatrix profesional adalah salah satu cara baginya untuk melawan patriarki dan segala ketidakleluasaan sosial yang diakibatkannya, dan dengan menjadi seorang dominatrix, ia mampu menterapi kliennya secara psikologis dalam bentuk pembebasan dan kenikmatan. Namun, Ia sendiri masih terkadang merasa malu dan mendiskriminasi pekerjaan tersebut secara internal karena masih banyaknya stigma terhadap pekerjaan ini: Ia belum bisa seutuhnya mengaktualisasi dirinya. Setelah memberanikan diri untuk membuka diri ke- kepada tokoh Doug, seseorang yang ia sukai dan menerima Tiffany apa adanya, Tiffany pun tersadar bahwa satu-satunya yang menjadi penghambat di dalam memaksimalkan potensinya adalah dirinya sendiri. Pada akhirnya, dengan mengenakan atribut dan kostum dominatrix lengkap, Tiffany maju dan mempresentasikan di depan teman-teman sekelasnya dan menunjukkan bahwa wujud dan metode inilah yang ingin ia terapkan ketika nanti ia menjadi psikolog. Dengan kata lain, dengan meyakini dan menerima identitasnya sebagai dominatrix sebagai bagian jati dirinya, Tiffany pun akhirnya mampu memenuhi kebutuhan aktualisasi dirinya.

Di dalam piramida kebutuhan Abraham Maslow, kebutuhan akan aktualisasi diri merupakan kebutuhan dasar tertinggi manusia. Berbeda dengan ke-empat kebutuhan lainnya (fisiologis, rasa aman, kasih sayang/sosial, dan penghargaan diri), semakin terpenuhinya kebutuhan akan aktualisasi diri, motivasi seseorang akan semakin bertambah dan bukannya berkurang (McLeod 2020). Aktualisasi diri merepresentasikan pengembangan diri individu menuju pemenuhan kebutuhan tertinggi, khususnya kebutuhan-kebutuhan untuk makna hidup. Usaha-usaha seseorang dalam mengaktualisasi dirinya merupakan usaha-usaha dalam meraih potensinya dan memenuhi dirinya (self-fulfilling) secara maksimal. Untuk dapat mengaktualisasi diri secara maksimal, seseorang harus sudah menemukan dan mengenal jati dirinya dengan baik. Bagi pemuda, proses aktualisasi diri merupakan sebuah tantangan tersendiri. Kesulitan-kesulitan yang dihadapi pada masa-masa transisi yang dialami pemuda mendisrupsi dan mendistraksi pencarian jati diri dan-oleh sebab itu-aktualisasi diri mereka.

Sebagai karier yang merupakan ekspansi dari nilai-nilai yang dianut sebuah subkultur, karir subkultural menawarkan kesempatan pemuda untuk mengaktualisasi dirinya dengan sedikit berbeda dengan karir-karir di industri budaya dominan. Kebanyakan industri budaya dominan bersifat formal, memiliki jenjang karir yang cenderung kaku, dan dianggap sebagai industri 'normal' dibandingkan industri subkultural yang dianggap cenderung 'menyimpang', tidak menjamin masa depan karena terlalu 'luwes' dan 
lebih bersifat informal. Di dalam karier subkultural, setiap pekerja termasuk kelompok pemuda merupakan bagian dari subkultur itu sendiri sebagai sebuah kelompok. Sense of belonging dan keterikatan personal para pekerja industri subkultural lebih kuat dibanding industri konvensional. Sehingga, ketika mereka mengembangkan potensi di dalam karir, mereka sekaligus juga mengaktualisasi diri secara personal.

\section{Karier Subkultural: Pemuda Marginal Perkotaan dan Strategi Bertahan Hidup}

Tiffany adalah seorang perempuan muda dan Pete adalah seorang laki-laki muda homoseksual. Keduanya berusia 20-an awal dan bukan berasal dari kalangan elit. Meskipun di dalam serial Bonding tidak diceritakan kesulitan-kesulitan khusus yang mereka hadapi dalam mendapatkan pekerjaan di bidang formal karena identitas mereka sebagai anggota kelompok minoritas/rentan, tetapi mereka digambarkan memiliki perjuangan tersendiri untuk bertahan hidup di kota besar New York City. Tokoh Pete diceritakan sebagai pemuda yang baru memulai kariernya di industri subkultural kink dan komedi stand-up. Berasal dari kota kecil di salah satu negara bagian konservatif, Pete tinggal di sebuah apartemen sempit di New York City. Masih belum jelas apa motivasi terbesar yang mendorongnya untuk memilih tinggal di New York City (NYG), tetapi Pete digambarkan memiliki minat untuk menjadi seorang komedian stand-up. Sementara ia mempersiapkan untuk terjun ke dunia stand-up, Pete bekerja sebagai pelayan di rumah makan untuk membiayai kehidupannya sehari-hari. Pete sendiri diceritakan sempat menempuh pendidikan tinggi, namun tidak dijelaskan apakah ia lulus dan memiliki gelar Sarjana. Di dalam episode-episode Bonding; Pete diilustrasikan mengalami kesulitan finansial. Bahkan untuk membayar sewa apartemennya, ia tidak memiliki cukup uang. Di saat itulah ia memutuskan untuk menerima tawaran Tiffany untuk bekerja sebagai asistennya. Walaupun pekerjaan tersebut awalnya membuatnya merasa tidak nyaman dan mengharuskannya untuk bekerja malam hingga pagi hari, Pete tetap menjalaninya. Di luar itu, Pete masih mencari-cari kesempatan untuk mendapatkan uang tambahan dengan melakukan kerja seks 'freelance' meskipun hal-hal tersebut membuatnya terpaksa keluar dari zona nyaman. Setelah memiliki dua pekerjaan, Pete ternyata masih menginginkan untuk tetap mencoba peruntungan di bidang komedi stand-up.

Usaha-usaha yang dilakukan tokoh Pete di atas menggambarkan perjuangan seorang pemuda kelas menengah yang berasal dari kota kecil untuk bertahan hidup setelah menjadi anggota masyarakat di kota besar. Rightor Doyle, sang kreator, pun mengakui bahwa penulisan tokoh Pete terinspirasi dari pengalamannya sendiri ketika ia berusia 22 tahun. Pada waktu itu, teman perempuan Doyle, seorang dominatrix profesional, memintanya sebagai asisten ia ketika sedang berjuang memulai karirnya sebagai aktor dan komedian di NYC. Sekalipun beragam dan akrab dengan keberagaman, masyarakat kota besar seperti NYC masih terbagi berdasarkan kelas sosial, bahkan kesenjangan ini semakin besar angkanya seiring semakin besarnya sebuah peradaban kota (Berube and Holmes 2015). NYG sendiri memiliki kesenjangan pendapatan yang sangat tinggi, yaitu 0,5-0,6 skala Gini Koefisien di tahun 2006. Artinya, $1 \%$ dari populasi memiliki $49-59 \%$ dari total kekayaan yang ada. Lebih lanjut lagi, di Amerika Serikat, kelas sosial tidak hanya ditentukan berdasarkan pendapatan atau nilai kekayaan seseorang, tetapi juga kekuasaan politik dan hak istimewa yang dimiliki suatu kelompok berdasarkan etnis atau rasnya. Sehingga, meskipun terbuka dengan keberagaman, kota besar seperti NYC masih memiliki masyarakat yang terbagi menjadi kelompok dominan dan kelompok minoritas. Kelompok minoritas juga disebut dengan kelompok rentan karena kecenderungan mereka yang lebih riskan untuk menerima perilaku kekerasan, diskriminasi, dan ketidakadilan, baik secara fisik, psikis, ekonomi, termasuk dalam hal pekerjaan. Kelompok rentan cenderung kurang diinginkan oleh perusahaan atau industri karena berbagai alasan, mulai dari kebutuhan khusus, stigma, hingga menjaga reputasi. Sebagai contoh, perempuan akan membutuhkan hari libur khusus ketika menstruasi dan hamil. Bagi perusahaan, hal ini dapat merugikan mereka secara ekonomi. Contoh lainnya, pemberi kerja www.jurnal.ugm.ac.id/jurnalpemuda 
ragu untuk mempekerjakan seorang homoseksual terbuka, karena masih banyak stigma di masyarakat. Apabila anggota kelompok rentan ini sudah direkrut menjadi karyawan pun, diskriminasi masih sering harus mereka hadapi. Di dalam penelitian yang dilakukan kepada kelompok minoritas seksual muda di Detroit, Amerika Serikat, terhitung sedikitnya 15 persen mengalami diskriminasi paling tidak satu kali dalam setahun terakhir (Bauermeister, et al. 2014).

Berkarier subkultural bisa menjadi alternatif pilihan karier yang tidak pandang bulu mengenai identitas pekerjanya. Terlebih jika pekerja tersebut termasuk di dalam dan memiliki talenta dan kemampuan yang dihargai di budaya subkultur itu sendiri, serta memiliki latar belakang yang sama-sama bukan berasal dari kelompok/budaya dominan. Berkarier subkultural dapat memberikan keluwesan dalam mengatur waktu bekerja dan kebebasan dari aturan-aturan formal yang mengikat. Sehingga, seseorang dapat saja berprofesi di lebih dari satu pekerjaan subkultural demi memenuhi kebutuhan finansialnya. Sebagai kota metropolitan, NYC memiliki daya tarik tersendiri bagi masyarakat dari segala penjuru Amerika Serikat, bahkan dunia, untuk mengadu nasib dan mengecap indahnya The American Dream. Hal inilah yang membuat populasi NYC dan kota-kota besar lainnya seperti Jakarta, Sydney, atau London memiliki keragaman yang lebih dibandingkan kota-kota lainnya yang lebih kecil. Di samping keragaman latar belakang etnis dan budaya, masyarakat kota-kota besar ini juga cenderung lebih terbiasa dengan keberagaman seksualitas, kelompok sosial, dan agama dibanding kota-kota lain yang cenderung homogen. Keragaman inilah salah satu faktor yang mendorong kemunculan kelompok-kelompok subkultur, termasuk di antaranya yang dapat mengakomodasi karir subkultural.

D. Kritik: Realita vs Potret Pekerja Industri Seksual dalam Bonding

Meskipun menceritakan potret kehidupan dunia BDSM, menurut para dominatrix profesional di dunia nyata, cerita serial Bonding dianggap kurang merepresentasikan realita secara utuh (Blunt 2019).
Dalam serial ini, kepribadian Tiffany digambarkan sebagai sosok yang dingin dan tidak membiarkan orang lain mengakses sisi emosionalnya, yang secara implisit dianggap sebagai persyaratan dari pekerjaannya sebagai dom. Menurut Mistress Couple (dalam Dickson 2019), seorang dominatrix profesional senior, seringkali, pada kenyataannya bekerja dalam industri seks bukan mengenai pelampiasan atau perpanjangan dari jati diri seseorang, tetapi mengenai pekerjaan itu sendiri, mengenai bagaimana mereka harus mencari penghasilan untuk bertahan hidup. Sebagian besar dom yang dikenal Mistress Couple bukan perempuan pasif-agresif yang melampiaskan trauma mereka kepada klien (Ibid,.).

Selanjutnya, di Amerika Serikat, di mana isu rasisme masih sangat kerap ditemui, potret yang digambarkan Bonding dianggap masih menggambarkan sosok pekerja subkultural yang memiliki privilese kulit putih dan kurang memiliki kerentanan berlapis atau interseksional. Di episode terakhir, Tiffany dan Pete diceritakan sedang melayani house call $\urcorner$ seorang pebisnis laki-laki kaya. Pebisnis ini menuntut dan memaksa Tiffany untuk memberikan layanan yang bukan bagian dari kesepakatan dan mengancamnya dengan pisau. Akhirnya, Tiffany mampu meloloskan diri bersama Pete setelah menusuk si pebisnis dengan pisau. Padahal, ketika hal tersebut terjadi kepada pekerja seks dari ras minoritas, kemungkinan besar ceritanya bisa berbeda. Sebagai contoh, seorang pekerja seks kulit hitam bernama Alisha Walker dijatuhi hukuman 15 tahun penjara setelah dinyatakan bersalah atas kasus pembunuhan terhadap kliennya, seorang guru sekolah Katolik berusia 61 tahun. Padahal, yang dilakukan Alisha adalah reaksi pertahanan diri karena si klien memukulnya dan mengancamnya dengan pisau akibat sebuah kesalahpahaman (Beccerill 2017). Hal ini menunjukkan besarnya 'harga' yang harus dibayar dan risiko yang harus dihadapi oleh para pekerja seks-khususnya yang berasal dari golongan minoritas-ketika menjalani pekerjaannya untuk bertahan hidup.

Selanjutnya, di salah satu episode, Tiffany mengeluh kepada Pete tentang ketidakadilan yang harus dialaminya sebagai perempuan dan stigma yang harus ia tanggung sebagai pekerja seks. Namun say- 
angnya stigma ini tidak dibahas maupun digambarkan lebih lanjut dalam cerita. Salah satu alasannya ialah karena hal inilah yang memang dengan sengaja ingin disampaikan oleh Rightor Doyle, sang penulis cerita dan sutradara Bonding, kepada New York Post. Doyle menginginkan serial ini untuk bisa mengeliminasi stigma mengenai kerja seks dan seksualitas alternatif (Dickson 2019). Padahal di dunia nyata, stigma masyarakat dan diskriminasi-diskriminasi inilah yang membuat pekerjaan subkultural, khususnya dalam dunia seks komersial dan kink, terasa tidak se-asyik dan semudah yang dibayangkan. Stigma-stigma tersebut meliputi bahwa pekerja seks menyebarkan penyakit menular seksual; pekerja seks mengidap HIV; pekerja seks memiliki moral yang rendah; pekerja seks memiliki permasalahan hidup dan trauma yang menyebabkan mentalnya terganggu, dan seterusnya. Menurut beberapa dominatrix profesional di dunia nyata, penggambaran karakter Tiffany di dalam Bonding juga memberikan kesan klise bahwa dominatrix memilih pekerjaannya karena mereka memiliki trauma di masa lalu (Dickson 2019). Hal ini dapat menjadi stigmatisasi baru yang menganggap bahwa semua dominatrix adalah korban trauma. Yang dikhawatirkan adalah hal ini dapat menjadikan para pekerja subkultural di bidang kerja seks dan seksualitas alternatif menjadi sebuah kelompok minoritas dan/ atau kelompok rentan tersendiri.

\section{KESIMPULAN}

Kota metropolitan merupakan peninggalan era industrial yang mana besarnya ukuran dan kekuatan sektor bisnis dan industri menarik pendatang dari penjuru negeri bahkan dunia untuk mengadu peruntungan mereka. Akibatnya, kota-kota besar cenderung memiliki masyarakat yang lebih heterogen dibanding kota-kota yang lebih kecil. Munculnya kelompok-kelompok subkultur di kota-kota besar merupakan salah satu konsekuensi dari keberagaman masyarakat di kota besar itu sendiri. Di setiap peradaban, masyarakat dengan sendirinya akan membentuk kebudayaan dominan yang mengusung nilai-nilai yang dianggap normal, dan kebudayaan apapun selain itu, akan dianggap sebagai ke- budayaan alternatif atau subkultural.

Begitu pula dengan pekerjaan. Karier subkultural muncul sebagai alternatif dari karier-karier normal dan formal yang kita ketahui selama ini, seperti dalam industri korporasi, perbankan, pendidikan, kesehatan, dan sebagainya. Pekerjaan-pekerjaan tersebut banyak diminati karena dapat lebih menjamin masa depan dan kepastian kerja. Dengan banyaknya peminat, persaingan menjadi semakin ketat, terlebih bagi kelompok masyarakat rentan seperti pemuda, perempuan, LGBTQ+, dan kelas proletar. Maka, demi penghidupannya, kelompok masyarakat ini memilih untuk berkarier dalam sektor informal maupun subkultural.

Dalam serial Bonding; keberagaman dan ritme kehidupan yang serba cepat di kota New York menghasilkan kemunculan berbagai subkultur, salah satunya subkultur kink atau seksualitas alternatif, yang mana mengakomodasi karier-karier seperti dominatrix profesional. Setelah ditelaah, dalam serial ini, selain memilih menekuni karier subkultural sebagai dominatrix profesional sebagai strategi bertahan hidup, pemuda dengan identitas rentan juga memanfaatkan karier tersebut sebagai sarana sekaligus motivasi untuk mengaktualisasi diri mereka. Akan tetapi, sebagai produk media fiksi, cerita dalam Bonding memang didramatisir dan dibuat sedemikian rupa demi kepentingan hiburan, sehingga tidak selalu sesuai dengan yang terjadi di kehidupan nyata.

\section{DAFTAR PUSTAKA}

Anderson, James A. 2011. Media Research Methods: Understanding Metric and Interpretive Approaches. Thousand Oaks: SAGE Publications.

Arora, Shilpa Kanna, Dheeraj Shah, Sanjay Chaturvedi, and Piyush Gupta. 2015. "Defining and Measuring Vulnerability in Young People." Indian Journal of Community Medicine 40 (3): 193-197.

Badgett, M.V. Lee, Laura E. Durso, and Alyssa Schneebaum. 2013. New Patterns of Poverty 
in The Lesbian, Gay, and Bisexual Community. Los Angeles: The Williams Institute.

Bauermeister, Jose A., Steven Meanley, Andrew Hickok, Emily Pingel, Willam VanHemert, and Jimena Loveluck. 2014. "Sexuality-Related Work Discrimination and Its Association with the Health of Sexual Minority Emerging and Young Adult Men in the Detroit Metro Area." Sexuality Research and Social Policy 11 (1): $1-10$.

Beccerill, Crystal Stella. "Why Is This Sex Worker In Jail For Surviving?" The Fader, February 16, 2017, https://www.thefader.com/2017/02/16/ alisha-walker-sex-worker-murder-support.

Berube, Alan, and Natalie Holmes. 2015. Some Cities Are Still More Unequal than Others-an update. Washington, DC.: The Brookings Institution.

Blunt, Mistress. "A Dominatrix Reviews 'Bonding,' Netflix's Show About a Dominatrix." Vice, April 29, 2019, https://www.vice.com/en_us/ article/3k3b8n/bonding-netflix-review.

"Bonding (episode 1): Old Friends, New Names, " directed by Rightor Doyle, written by Rightor Doyle, featuring Zoe Levin and Brendan Scannell, aired April 24, 2019, on Netflix, https://www.netflix.com/search?q=bonding\&$\mathrm{jbv}=81004814 \& \mathrm{jbp}=0 \& \mathrm{jbr}=0$.

Bollens, Scott A. 2005. "Ethnic Conflict." In Encyclopedia of The City, 239-241. New York City: Routledge.

Conti, Uliano. 2016. "Subculture. State of the Art and Future Perspectives in Sociology." Democracy \& Security Review 6 (2): 191-210.

DiCesare, Mariachiara. 2014. "Women, Marginalization, and Vulnerability: Introduction." Genus 70 (2-3): 1-6.

Dickson, EJ. "Sex Workers Aren't Happy With the New Netflix Show About Dominatrixes." Rolling Stone, April 29, 2019, https://www. rollingstone.com/culture/culture-features/ bonding-dominatrix-show-netflix-sex-workers-reaction-828552/.

"Definition of Marginalized Groups." 2020. European Institute for Gender Equality. Retrieved
March 1, 2020 (https://eige.europa.eu/thesaurus/terms/1280).

Faccio, Elena, Claudia Casini, and Sabrina Cipolletta. 2014. "Forbidden games: the construction of sexuality and sexual pleasure by BDSM players." Culture, Health \& Sexuality 16 (7): 752-764.

Fischer, Claude S. 1995. "The Subcultural Theory of Urbanism: A Twentieth-Year Assessment." American Journal of Sociology 101 (3): 543577.

Foucault, M., 1978. The History of Sexuality: Vol. 1. An introduction (R. Hurley, Trans.). New York: Pantheon.

Gallie, Duncan, and Serge Paugam. 2002. Social Precarity and Social Integration. Brussels: European Commission, Directorate General for Employment and Social Affairs.

Gamarel, Kristi E., Sari L. Reisner, Jeffrey T. Parsons, and Sarit A. Golub. 2012. "Association Between Socioeconomic Position Discrimination and Psychological Distress: Findings From a Community-based Sample of Gay and Bisexual Men in New York City." American Journal of Public Health 102 (11): 2094-2101.

Graham, Benjamin C., Sarah E. Butler, Ryan McGraw, Shelby Marie Cannes, and Joanna Smith. 2016. "Member Perspectives on the Role of BDSM Communities." Journal of Sex Research 53 (8): 895-909.

Graham, Mark. 2014. Queer Interventions: Anthropological Explorations in Queer Theory. London and New York: Routledge.

Jensen, Klaus Braun. 2013. A Handbook of Media and Communication Research: Qualitative and Quantitative Methodologies. London: Routledge.

Kaur, Anjali. 2007. Women's Economic Empowerment: Meeting the Needs of Impoverished Women. New York: United Nations Population Fund.

KOMNASHAM. 2016. Pemenuhan Hak Kelompok Minoritas dan Rentan di Indonesia. Jakarta: Komisi Nasional Hak Asasi Manusia Republik Indonesia. 
Lehmiller, Justin J. 2018. Tell Me What You Want: The Science of Sexual Desire and How It Can Help You Improve Your Sex Life Tell Me What You Want: The Science of Sexual Desire and How It Can Help You Improve Your Sex Life. New York: De Capo Press.

Littlejohn, Stephen W., Karen A. Foss, and John G. Oetzel. 2016. Theories of Human Communication. 11th. Long Grove: Waveland Press, Inc.

McLeod, Saul. "Maslow's Hierarchy of Needs." Simply Psychology. March 20, 2020. https:// www.simplypsychology.org/maslow.html.

Minza, Wenty Marina. 2014. "Masa Muda Sebagai Masa Transisi." 3-18. In Buku Panduan Studi Kepemudaan, edited by M. Najib Azca, Derajad S. Widhyarto, and Oki R. Sutopo. Yogyakarta: Yousure Fisipol UGM.

Nilan, Pamela, Roberta Julian, and John Germov. 2007. Australian Youth: Social and Cultural Issues. Australia: Pearson Education.

Offerdahl, Kate, Alicia Evangelides, and Maggie Powers. 2014. Columbia Global Policy Initiative. New York: Columbia University.

Pinksy, Dina, and Tania G. Levey. 2015. "A world turned upside down': Emotional labour and the professional dominatrix." Sexualities 18 (4): 438-458.

Snyder, Gregory F. 2017. "Deviance as Career Opportunity: The Case of Graffiti and Skateboarding." In Routledge Handbook of Deviance, by Stephen E. Brown and Ophir Sefiha, 130-138. New York: Routledge.
Sperner, Elena. 2016. "'Your Kink is Not My Kink, But That's OK" : Deconstructing Sexual Deviance and the Stigma on BDSM". Thesis, University of Stockholm.

Sprott, Richard, and Anna Randall. 2016. BDSM/ Kink and Therapy: Experiences of Stigma and Resiliency. San Fransisco: AAMFT 6th Annual California Division Conference Dimensions of Cultural Diversity in Couples and Families: Race, Gender, and Social Justice San Francisco State Univ.

Sutopo, Oki Rahadianto, and Nanda H.P. Meiji. 2014. "Transisi Pemuda dalam Masyarakat Risiko: Antara Aspirasi, Hambatan dan Ketidakpastian." Jurnal Universitas Paramadina 11(3): 1164-1186.

Toska, Stravoula. 2019. "I Worked As A Dominatrix For Over 5 Years. Here's What It's Really Like." The Huffington Post, March 8, https:// www.huffpost.com/entry/working-as-a-dominatrix_n_5c66ea02e4b033a799423973.

Weinberg, Thomas S. 2006. "Sadomasochism and The Social Sciences: A Review of The Sociological and Social Psychologicall Literature." Journal of Homosexuality 50 (2-3): 17-40.

Zakiah, Naila Rizqy. 2018. "Pengaduan perempuan transgender ke Komnas Perempuan: 'Tinggal di kos sendiri pun diusir." By BBC Indonesia, BBC Indonesia, November 24, https://www. bbc.com/indonesia/indonesia-46320045. 